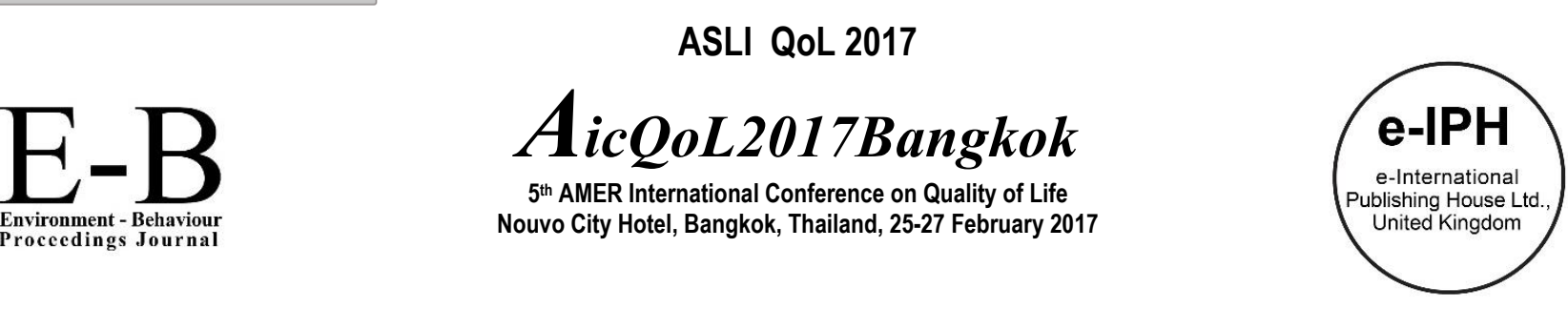

\title{
The Role of Universal Design on Campus and Practical Mobilisation
}

\author{
Sridara Tipian *1 , Antika Sawadsri 2 \\ ${ }^{1}$ Arch D. Student, Multidisciplinary Design Research Program, \\ Faculty of Architecture, King Mongkut's Institute of Technology Ladkrabang (KMITL), Thailand. \\ 2 Asst. Prof., Ph.D., Faculty of Architecture, King Mongkut's Institute of Technology Ladkrabang (KMITL), Thailand,
}

\begin{abstract}
Research on universal design implementation in a private university. Objective is to investigate physical environment and facilities on campus under the concept of universal design together with standard by Thai law and studied perception of the executive's management as well as users' attitude within the area. A case study of Dhurakij Pundit University in Bangkok by survey, site observation and investigation of Universal Design implemented, interviewing the executive's management and open-ended questionnaires with personnel and students. The findings of this research may be used as reference to initiative universal design implementation and develop for well environment in the future.
\end{abstract}

Keywords: universal design implementation; physical environment; private university; campus

ISSN: 2398-4287@ 2017. The Authors. Published for AMER ABRA by e-International Publishing House, Ltd., UK. This is an open access article under the CC BYNC-ND license (http://creativecommons.org/licenses/by-nc-nd/4.0/). Peer-review under responsibility of AMER (Association of Malaysian Environment-Behaviour Researchers), ABRA (Association of Behavioural Researchers on Asians) and cE-Bs (Centre for Environment-Behaviour Studies), Faculty of Architecture, Planning \& Surveying, Universiti Teknologi MARA, Malaysia.

\subsection{Introduction}

To bring the principles and concepts of the universal design to be used in schools and universities had become integrated to develop the country. Education places are human capital sources, can support and prosper people to be responsible with qualifications and welcomed everyone to study equally, comply with Thailand's act: education for persons with disabilities B.E. 2008, section 5 stated that disabilities have the right to get facilities, media, services and assistances without pay. Therefore all public and private schools and universities had to renovate the environment and supply all convenience facilities for the disabilities and all people. However the universal design in operation by public school and universities been clearly well aware and easily acted than private school and universities due to the differences in process of the management projects. In this research aimed to investigate the universal design in operation according to the physical environment and facilities of universal design within Dhurakij Pundit University under the concept of universal design together with Thai laws and studied the perception of the executive's management as well as users' attitude within the area. From research has found showed that the understanding and management's intention been the master key to push the universal design and it was important to enhance the understanding of problems to the executives (Saito, 2006) and the precise knowledge of universal design needs to be enhanced among the building managers. (Syazwani Abdul Kadir, 2012) From the studies, results could be analyzed and summarized to be further developed for the universal design as per the legal requirements and suitable to a comply setting for Dhurakij Pundit University.

\subsection{Literature Review}

\subsection{The Concept of Universal Design}

There are many educated experts and designers in Thai society, who had known well in principles and concepts of the universal design, also the government realized to the effects of inconvenience facilities environment to societies that would not be hospitable to

\footnotetext{
${ }^{*}$ Corresponding author. Tel.:

E-mail address: t_darada@hotmail.com
}

ISSN: 2398-4287@ 2017. The Authors. Published for AMER ABRA by e-International Publishing House, Ltd., UK. This is an open access article under the CC BYNC-ND license (http://creativecommons.org/licenses/by-nc-nd/4.0/). Peer-review under responsibility of AMER (Association of Malaysian Environment-Behaviour Researchers), ABRA (Association of Behavioural Researchers on Asians) and cE-Bs (Centre for Environment-Behaviour Studies), Faculty of Architecture, Planning \& Surveying, Universiti Teknologi MARA, Malaysia

DOI: http://dx.doi.org/10.21834/e-bpj.v2i5.665 
life such as occupation, education and so on. Such obstacles had been effective directly to people, who are the heart of country's development. According to the national economic and social development plans that needed for people to be centered by encouraging and potentialities together with environment developing. The universal design is other passage to improve infrastructure services (Department of public works Bangkok, 2013). This idea had been applied to be easily understanding and widely used by the center for universal design by North Carolina State university (1997) with 7 items: 1) Equitable use; design will be useful and needed to many kinds of people than one group 2) Flexibility in use; design will be served to various person's abilities 3) Simple and intuitive use; easy to understand 4) Perceptible information; efficient the necessary details without any different knowledge or conditions of users to be limited in use 5) Tolerance for error; design to be harmless to users even by mistake in use 6) Low physical effort; design to be usable without forced 7) Size and space for approach and use; design should have suitable space to be reachable, touchable and any sizes of users with movable action. Universal design could be combined with other facilities for higher quality of life. Universal design could be taken into account and renovate the surroundings to better environment facilities to maximize the benefits. In the event that will push society and the concept to access and can use to all groups of people. Incorporating the concepts of universal design Proposed that the overall benefits in various dimensions in Table 1

Table 1. Shown overview benefits of universal design

\begin{tabular}{c|l}
\multicolumn{1}{c}{ Table 1. Shown overview benefits of universal design } \\
\hline Benefits & \multicolumn{1}{c}{ Overview benefits of universal design from the merger ideas } \\
\hline $\begin{array}{c}\text { Disabilities and } \\
\text { older people }\end{array}$ & $\begin{array}{l}\text { - Disabilities and older people can help themselves and proud to their abilities, have strong minds and ready to face } \\
\text { with obstacles. } \\
\text { - Improve disabilities and older people to be powerful of the nation } \\
\text { (Department of Public Works Bangkok, 2013) }\end{array}$ \\
\hline \multirow{3}{*}{ Persons } & $\begin{array}{l}\text { - Support to be easily and convenient used, respected to humanity and privacy } \\
\text { - Support to ease difficulties in product using, services in any differential surroundings } \\
\text { - Everyone can use all facilities, services and any normal surroundings }\end{array}$ \\
\hline \multirow{3}{*}{ Social } & $\begin{array}{l}\text { - Support to access and usable to all people with free living to use services and environment by themselves. } \\
\text { - Universal design assumed that the range of human availabilities are different as per activities and environment } \\
\text { (Ostroff, 2001), thus the facilities, services and built environment could be used to all people regardless of ages, sizes, } \\
\text { abilities or disabilities } \\
\text { - Innovation Technology, which used to social facilities to users with differences of abilities, gender, ages will be } \\
\text { equally to easy living and safer to all people }\end{array}$ \\
\hline
\end{tabular}

This research had taken the 7 principles and overview benefits from integration's concept of the universal design (Table 1) to be main idea to reduce development impacts from social environment which were not supported to living and social participation by stress the universal design in public buildings in the universities in believe that they are places where everyone can equally access to study and welcome to all incomers.

2.2 Thai Laws and the Universal Design

Although everybody knows that universal design is very useful when the principles had been in actions, which would be affect the physical of environment changed under the roles of laws, included the cost of constructions or infrastructure. The results might not be enough to faster motivation to follow the role of universal design. Whenever the laws have been standard to practice mobilisation with clear guideline to follow.

Nowadays in Thailand had used national economic and social development plan, which supported to build up the capacity of people together with environment developing to strengthen the family and communities. Human capital development is of supreme importance for the country's development. From this conclusion the researcher focused to study that human capital could be improved and value added as one of the factors. Schools and universities are places to produce human capital. Education urged people to be thinking with enthusiasm, efforts and ready to improve or reform for the better. Campus therefore should offer all convenient facilities and opened for students to study equally and user-friendly to all. Schools and universities should well aware to the differences in physical persons and serve them with all facilities equally. Thai government has developed legislation to focus on the quality of life, which are regulations required for convenience facilities for disabilities or handicapped and old people in the buildings B.E.2005, vol.no.122 part 52A indicated that convenience facilities must be supported for disabled, handicapped and old people. The act of the enhancement and quality of life chronicles B.E. 2007, Section 20 said that the disabilities have the right to get and use from all convenience facilities which are public services and other assistances from the state. The act of the education for persons with disabilities_act 2008,_section 5 indicated that disabilities have the right to get free education since born and receive convenience accommodations, media, services and assistances without pay. The act of education B.E. 2009, section 10 also indicated that everyone has the right to have equally education and the ministerial regulations B.E. 2005 set for convenience accommodations for the disabilities and the old people in the buildings that built after B.E.2005. The councils of ministers agreed on the urgent agenda for the buildings to set up the facilities at five parts, especially in the governments' and public buildings, which are sloping passages, restrooms, parking areas, sign and symbols, and information departments, had begun within the hospitals first, however there was a loophole in the law for other public buildings built before B.E. 2005. The law needed to develop further on.

\subsection{Essentials Elements in Campus under the Universal Design}

To study environment and convenience facilities designed in the universities is very important to make friendly surroundings to all participants. The designs could be referred from the essential element to reduce the effective social surroundings that not conductive to access and to participate in activities in the universities, which were 1) Basic convenience facilities for disabilities as per the council 
of ministers dated May 19, 2009 (2) The facilities in buildings as per ministerial cabinet B.E. 2005 (3) Literature review for facilities of universal design in campus (Atkinson et al., 2013) as shown in Table 2.

Table 2. Essential element to reduce the effects of unfavorable access and ways to participate in activities within social surroundings in campus

\begin{tabular}{l|l|l|l}
\hline $\begin{array}{l}\text { (1) Basic convenience facilities for } \\
\text { disabilities as per the council of } \\
\text { ministers dated May 19, 2009 }\end{array}$ & $\begin{array}{c}\text { (2) The facilities in buildings as } \\
\text { per ministerial cabinet B.E. 2005 }\end{array}$ & \multicolumn{2}{|c}{$\begin{array}{c}\text { (3) Literature review for facilities of universal design in campus } \\
\text { (Atkinson et al., 2013) }\end{array}$} \\
\hline 1.Ramps & 1. Parking & 1.Entrances & 8.Surface finishes \\
2. Restroom & 2. ramps & 2. Doors & 9.Internal lighting \\
3. Parking & 4. Signs and symbols & 3.Reception, Waiting and & 10.Vertical circulation \\
4.Signs and symbols & administrative office areas & 11.Internal stairs \\
5.Information \& services & 5. elevators & 4. Hallways & 12. Internal ramps \\
& 6. Stairs & 5.Classrooms & 13. elevators \\
& 7. Handrail & 6.Cafeteria & 14.Restroom and dressing \\
& 8. door & 7.Building layout & \\
& 9.Circulation and corridor & & \\
\hline
\end{tabular}

\subsection{Methodology}

This research also focused to study the implementation scenarios of universal design in private university; case study: Dhurakij Pundit University, which is the medium size private university in Bangkok with old and new school buildings. The university is developing management structure and physical environment. By the way the researcher could access to get information in depth. From this research model shown the principles and concepts of universal design, the legal requirements and the concept design environment in university, with all three concepts must be worked out together. See Fig.1

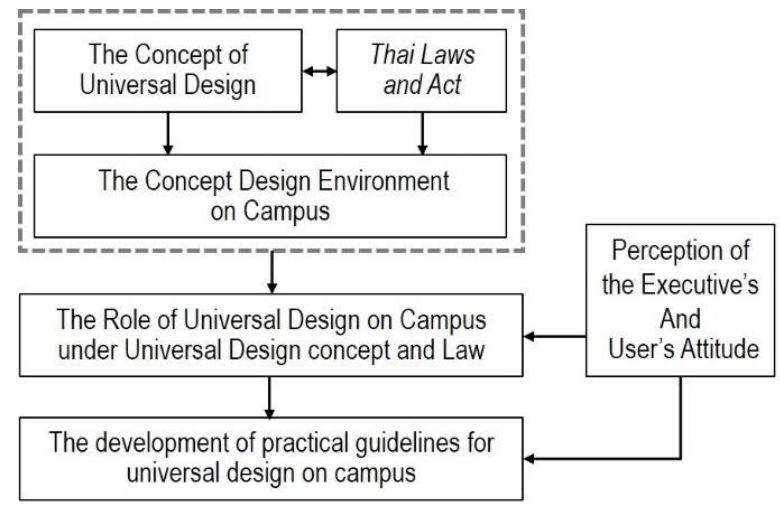

Fig. 1: Conceptual Framework.

The process of this research divided into two parts as followed:

Part 1:

Studied the physical surroundings and convenience facilities in the university under the principles and theories of universal design together with the present specifications of Thai laws. The determination by research tools were the survey forms with necessary factors that would reduce the effectiveness from social surroundings that were not allowed to access the activities in Dhurakij Pundit University (See.Fig.2), which concluded from literature review and from design criteria by legal requirements. The checklists were into;

1) Outdoors universal design with necessary elements were; signs and symbols, seating, path way/walk way, map, parking, curbs ramps, outdoor-ramps, street landscape, pedestrian crossing, street furniture and outdoor lighting.

2) Indoors universal design with necessary elements were; ramps into the buildings, entrance, elevator, sign and symbols, stair, restroom, tactile surface, service zone, door, railing and handrails, information, map, walkway and classroom.

The researcher took these research tools to check with elements inside the case study area by survey forms, observed and took photos, collected data in school buildings both the old building built before the year 2005 which had not required the buildings Legal Requirements and the new buildings built after year 2005 that were under the Ministerial Regulation for convenience facilities in buildings for disabilities or handicapped and older people B.E. 2005 and qualitative analysis. 


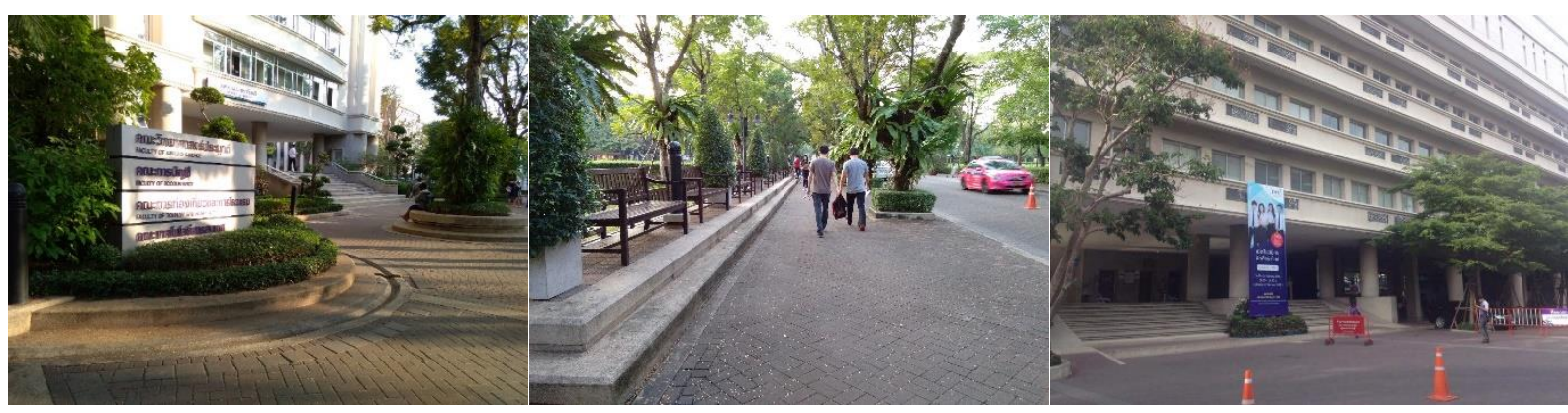

Fig.2: Physical Environment of Case Study

\section{Part 2:}

Collected data by individual interviews per person with partly tape- recorded allowance, used research tools by semi-structural interview from 2 selected groups: 1) The executives with decision-making powers to drive the universal design and 2) Users in area: personnel, students and staffs. Questions divided into 2 parts, firstly education, understanding to the principles and concepts of universal design. Secondly, views and opinions to universal design's concepts and their needs to the facilities which are necessary to do activities within the areas of university. In the part of the executive's interviews were questioned in depth for the policy and class actions, the things that could be done and trends to bring in use the universal design completely.

\subsection{Findings and Discussions}

Studied the access of universal design in private university, case study: Dhurakij Pundit University divided into 2 parts. The first part was results of research and what had found from study physical surroundings and convenience facilities under the standard of universal design together with conceptual design under the regulations. Data collected from outdoor and indoor buildings built before and after the legal requirements. The surveys checklists composed with necessary elements to reduce effects from social environment to be reachable and participle in activities as shown in Table 3.

Table 3. Shown results and checklists for physical environment with convenience facilities under the process of universal design in outdoor building together with the conceptual design under the legal requirements

\begin{tabular}{|c|c|c|c|}
\hline \multirow{2}{*}{$\begin{array}{l}\text { Necessary elements outdoor } \\
\text { buildings within the university }\end{array}$} & \multicolumn{2}{|c|}{ Area survey found } & \multirow{2}{*}{ Checklists with conceptual designed under the laws } \\
\hline & found & Not found & \\
\hline 1.Sign and Symbols & $\checkmark$ & & Info-signs were very few to see. Mostly stood under $2.00 \mathrm{~m}$, no tactile map \\
\hline 2.Seating & $\checkmark$ & & $\begin{array}{l}\text { Along the pathway found outdoor every distance for some parts. Seats were up stepped from ground } \\
\text { more than } 10 \mathrm{~cm} \text {. }\end{array}$ \\
\hline 3.Path way/ walk way & $\checkmark$ & & Path ways have been wide enough but lowered level and slope to the road only one side \\
\hline 4.Tactile Map & & $\checkmark$ & Not found \\
\hline 5.Parking & $\checkmark$ & & $\begin{array}{l}\text { Disabled parking been reserved in the center area near study buildings and office of the president, } \\
\text { accessible standard size } 2.4 \times 6.00 \mathrm{~m} \text {. free space for movement but no cleared signs and symbols to } \\
\text { show. }\end{array}$ \\
\hline 6.Curbs Ramps & $\checkmark$ & & $\begin{array}{l}\text { The curbs ramps had been standard with different colors to show the steps of roadsides but without } \\
\text { tactile surface to be advised. }\end{array}$ \\
\hline 7.Ramps & & $\checkmark$ & The steps outside been not much, so no ramps were made. \\
\hline 8.Pedestrian crossing & $\checkmark$ & & The steps between the road and footpath are equally, anyway no alarm-signs \\
\hline 9.Street Furniture & $\checkmark$ & & $\begin{array}{l}\text { Outdoor signs and symbols found only some and were standing under } 2.00 \mathrm{~m} \text {. Electric poles were } \\
\text { high, no alarm-warning }\end{array}$ \\
\hline 10.Lighting Outdoor & $\checkmark$ & & The university opened for evening courses so the electric lamps shown the ways clearly. \\
\hline
\end{tabular}

From Table 3 university had paid intention to the accessibility and taken action as per the legal requirements as well. The other necessities were not in process as per the universal design such as; aisle seats were not convenient to the disabled and the old people to step up over $10 \mathrm{~cm}$., parking area reserved for disabled only 1- 2 places with no clearly signs to be shown.

Table 4. Shown the survey and checklists of the physical environments and convenience facilities inside the buildings built before the legal requirements together with the conceptual universal design as per legal requirements

\begin{tabular}{l|l|l|l}
\hline $\begin{array}{c}\text { Necessity elements indoors } \\
\text { buildings built before the legal } \\
\text { requirements }\end{array}$ & frea survey found & \multicolumn{1}{c}{ Checklists with conceptual designed under the laws } \\
\cline { 2 - 3 } 1.Ramps & $\checkmark$ & Not found & \\
\hline 2.Entrance & $\checkmark$ & & $\begin{array}{l}\text { Most of the university's buildings built consecutively and before the legal requirements. Some } \\
\text { ramps could use for the disabilities but some could not just for delivered. }\end{array}$ \\
\hline 3.Elevator & $\checkmark$ & $\begin{array}{l}\text { Ground floor had enough free space for activities, elevator reachable. Doors are wide 1.00m. } \\
\text { With automatic hinge device. }\end{array}$ \\
\hline 4.Sign and Symbols, & $\checkmark$ & $\begin{array}{l}\text { Study buildings have 2 elevators with both small and big sizes, have movable space around } \\
1.50 \mathrm{~m} \text {. radius in front of the elevators, push buttons are at the suitable positions, no colors, no } \\
\text { alarm surface, no mirror and handrails inside. }\end{array}$ \\
\hline
\end{tabular}




\begin{tabular}{l|l|l|l}
\hline 5.Stair & $\checkmark$ & & The width of stair-rises, ladder and railing were standard. \\
\hline 6.Restroom & & $\checkmark$ & Been not arranged for the disabled in the buildings built before the legal requirements \\
\hline 7.Tactile Surface & & $\checkmark$ & Not found \\
\hline 8.Service zone & $\checkmark$ & & $\begin{array}{l}\text { Drinking water service machines were near the stairs but would be obstructed when in use. Other } \\
\text { services were in the areas of the central parts and closed to exit doors. }\end{array}$ \\
\hline 9.Door & $\checkmark$ & & Single open door with 0.90 wide, handle with door-knobs \\
\hline 10.Railing and Handrails & & $\checkmark$ & Not found \\
\hline 11. Information & $\checkmark$ & & Counter services were for general person, not suitable for the disabled. \\
\hline 12.Tactile Map & & $\checkmark$ & Not found \\
\hline 13.Walk way & & & $\begin{array}{l}\text { The width of walk ways in buildings were at 1.50m. Wide but there were benches along the way to } \\
\text { narrow and no handle rails. }\end{array}$ \\
\hline 14. Classroom & & $\checkmark$ & Simple classroom, which could rearrange to special case with the furniture and equipment. \\
\hline
\end{tabular}

The results of the survey and checklists indoors buildings built before the regulations from Table 4 found that the management lacked of practices and accessibilities as per the conceptual universal design, just only some parts had been rearranged but still not as per the legal requirements, there were still no restrooms for the disabilities in the buildings that built before the regulations although it is very important due to the council regulations.

Table 5. Survey results and the physical surroundings with convenience facilities checklists under the principles of universal design inside the buildings built after the legal requirements together with the conceptual by the Laws

\begin{tabular}{|c|c|c|c|}
\hline \multirow{2}{*}{$\begin{array}{l}\text { Necessity elements indoors } \\
\text { buildings built after the legal } \\
\text { requirements }\end{array}$} & \multicolumn{2}{|c|}{ Area survey found } & \multirow[b]{2}{*}{ Checklists with conceptual designed under the laws } \\
\hline & found & Not found & \\
\hline 1.Ramps & $\checkmark$ & & Found standard built, handle rails one side, no touching surface warning for the way up and down. \\
\hline 2.Entrance & $\checkmark$ & & $\begin{array}{l}\text { On the ground floor had wide open-space, elevator could be easily to use and doors to enter are } \\
1.00 \mathrm{~m} \text {. Wide, staircase with auto-door -hinge but no touching surface warning for the doorways. }\end{array}$ \\
\hline 3.Elevator & $\checkmark$ & & $\begin{array}{l}\text { Found } 4 \text { big size elevators with free space for movement by } 1.50 \mathrm{~m} \text {. radius, push buttons suitable } \\
\text { placed, but no colors to show, no warning tactile surface, no mirror and hand rails inside }\end{array}$ \\
\hline 4.Sign and Symbols, & $\checkmark$ & & $\begin{array}{l}\text { At ground floor signs stood under } 2.00 \text { meter high. Information signs were near stair or elevator } \\
\text { each floor, details were small sizes. }\end{array}$ \\
\hline 5.Stair & $\checkmark$ & & Stair-rises, ladders, railing are standard sizes. \\
\hline 6.Restroom & $\checkmark$ & & $\begin{array}{l}\text { Only one room on the second floor with size } 2.5 \times 2.5 \mathrm{~m} \text {. Movable, doorknobs push open with door } \\
\text { size } 1.00 \mathrm{~m} \text {. }\end{array}$ \\
\hline 7.Tactile Surface & & $\checkmark$ & Not found \\
\hline 8.Service zone & $\checkmark$ & & $\begin{array}{l}\text { Each floor had auto drinking machine indoor, but obstructed when in use. Other services located in } \\
\text { the center of management department near exit door. }\end{array}$ \\
\hline 9.Door & $\checkmark$ & & Usual one side door 0.90 wide, but study rooms will be double doors with knobs open. \\
\hline 10.Railing and Handrails & $\checkmark$ & & Only on the ramps to enter the building. \\
\hline 11. Information & $\checkmark$ & & Counter service was not suitable for the disabled. \\
\hline 12.Tactile Map & & $\checkmark$ & Not found \\
\hline 13.Walk way & $\checkmark$ & & Indoor- pavements were convenient with $1.50 \mathrm{~m}$. wide, but no hand rails found. \\
\hline 14. Classroom & & $\checkmark$ & The conventional classroom style with free space to use and can arrange for special requirements. \\
\hline
\end{tabular}

Finally the analysis of this survey results and monitoring the indoors buildings built after the regulations from Table 5 found that there were necessary legal requirements for the universal design already the main important elements to access the ramps to enter that really could be used, suitable width, elevator were big sizes, but mostly had no handrails and mirror, indoor pathways were wide, however this was the only one building that had restroom for the disabled persons. In conclusion from case study that in Dhurakij Pundit University the buildings built either before or after the legal requirements still could not be available to support to all people, the importance is only for the way to be reached than other subjects.

The conclusion for second part mostly aimed to the questions from sampling semi-structured interviews, mind knowledge concerned the universal design, experienced from facing convenience facilities and common uses of the area, convenience facilities needed in university advantages and disadvantages from applying to use the universal design.

In the section of the executive managements' interviewed in depth about the action to rearrange for the convenience facilities and trends to take the universal design in full line of actions. Research's results found;

Table 6. Shown the executive management's interviews

\begin{tabular}{c|l|l}
\hline Interviewee & \multicolumn{1}{c}{ Subject } & \multicolumn{1}{c}{ Perceptions } \\
\hline $\begin{array}{c}\text { Executive } \\
\text { managements }\end{array}$ & $\begin{array}{l}\text { Knowledge and understanding universal } \\
\text { design }\end{array}$ & $\begin{array}{l}\text { Principles and support to assist disabilities and older people and admitted to benefits of } \\
\text { the universal design been used in university }\end{array}$ \\
\cline { 2 - 3 } & Facilities needed in university & $\begin{array}{l}\text { Considered to the necessary conveniences and priorities to be renovated within the } \\
\text { essential areas, such as ramps, entrance, elevators. }\end{array}$ \\
\cline { 2 - 3 } & $\begin{array}{l}\text { The Advantages and disadvantages to adapt } \\
\text { using universal design }\end{array}$ & $\begin{array}{l}\text { The good : everyone got more convenience and benefits to social as a whole The bad : } \\
\text { to renovate high budget }\end{array}$ \\
\cline { 2 - 3 } & $\begin{array}{l}\text { Level to access universal design } \\
\text { students could consent the ways of life in the university. Universal design would be } \\
\text { accessed as per the Legal Requirements being forced or needed in area. }\end{array}$ \\
\hline
\end{tabular}




\begin{tabular}{l|l|l}
\hline & Facilities that can be supplied & $\begin{array}{l}\text { The university paid the most importance to the reachable areas and buildings at the first, } \\
\text { which were ramps, entrances, elevators, however plans to rearrange to meet with } \\
\text { standard requirements. }\end{array}$ \\
\cline { 2 - 3 } & Trend to take full practice & $\begin{array}{l}\text { As per the regulations by laws and social popular directions to be as part of the good } \\
\text { image and fringe benefits. }\end{array}$ \\
\hline
\end{tabular}

From Table 6. The knowledge and understanding of the executive managements in the universal design still paid more attention into the disabled and accepted to take the principle of universal design in use because it would be good for the private university to do as per the legal requirements. So far the university had no official policy for the disabled students yet therefore the renovation of the builds in full as per the universal design were not the most importance at present. The development will be gradually.

Table 7. Shown research's results from the representative sampling users in area by open-ended questionnaires

\begin{tabular}{|c|c|c|c|}
\hline & Interviewee & Subject & Perceptions \\
\hline \multirow[t]{4}{*}{1.} & \multirow{4}{*}{$\begin{array}{l}\text { Users' } \\
\text { representative in } \\
\text { area }\end{array}$} & $\begin{array}{l}\text { Knowledge and understanding universal } \\
\text { design }\end{array}$ & $\begin{array}{l}\text { Designed for the disabilities and responded to others and been public essential to } \\
\text { social benefits. }\end{array}$ \\
\hline & & $\begin{array}{l}\text { Experienced, found the facilities and also } \\
\text { shared the area }\end{array}$ & $\begin{array}{l}\text { Had seen curb ramps, seats on the bus and elevators, not many disabled persons to } \\
\text { share the area. If there would have more facilities to support them widely, it should } \\
\text { assist for the good relationship to each other. }\end{array}$ \\
\hline & & The needs for facilities in campus & $\begin{array}{l}\text { List from outdoor facilities required: 1) parking with signs 2) Seats for recreation } \\
\text { 3) Pavement and crossing with warning signs 4) Electric Lights 5) Curb ramps } \\
\text { - Indoor facilities required: 1) Restrooms 2) Elevator 3) Service Zone 4) Signs and } \\
\text { Symbols 5) Cleared signs for the entrance to buildings }\end{array}$ \\
\hline & & $\begin{array}{l}\text { Take action in the principle of universal } \\
\text { design in Dhurakij Pundit University }\end{array}$ & $\begin{array}{l}\text { To support the disabilities, to be interested in campus and would give the opportunity to } \\
\text { all to study equally and can accommodate people who might have got an accident }\end{array}$ \\
\hline \multirow[t]{4}{*}{2.} & \multirow[t]{4}{*}{$\begin{array}{l}\text { Disabled } \\
\text { representative }\end{array}$} & $\begin{array}{l}\text { Knowledge and understanding universal } \\
\text { design }\end{array}$ & $\begin{array}{l}\text { The conceptual of universal design would mainly support to the disabilities to be more } \\
\text { convenience. }\end{array}$ \\
\hline & & $\begin{array}{l}\text { Experienced, found the facilities and also } \\
\text { shared the area }\end{array}$ & $\begin{array}{l}\text { Had seen curb ramps to the buildings and walk way for the blinds, if there would have } \\
\text { more convenience facilities for the disabled persons, they might have come to join the } \\
\text { social activities and presented themselves. }\end{array}$ \\
\hline & & The needs for facilities in campus & $\begin{array}{l}\text { - Outdoor Lists for the convenience facilities required; 1) Ramps 2) Curb ramps } \\
\text { 3) Crossing way 4) Walk way -pavement 5) Street furniture } \\
\text { - Indoor list for the convenience facilities required; 1) Curb ramps into the buildings } \\
\text { 2) Restrooms 3) Handrails 4) Elevator 5) Service zone }\end{array}$ \\
\hline & & $\begin{array}{l}\text { Take action in the principle of universal } \\
\text { design in Dhurakij Pundit University }\end{array}$ & $\begin{array}{l}\text { Would help the disabilities to come and join activities in campus more convenience. } \\
\text { They can help themselves proudly and may not wait for help from the others. }\end{array}$ \\
\hline
\end{tabular}

The point of views and perception from two of the interview groups, most of them paid more attention to the disabled mainly, then the others would become too. As the interviewee were directly impacted so the needs of convenience facilities were clear and met with their requirements.

The first interviewee required the convenience facilities as visual elements with equal rating for using the common area and not understand why the disabled could not use the general area as well. The second interviewee mentioned that if the social surroundings were ready, the disabilities would have more places to join activities besides staying home. The first interviewee advised that if the universal design had been used in Dhurakij Pundit University, it would be the good opportunity for the disabilities to come and join the study more.

\section{Conclusion and Recommendations}

From research's results found that in planning to develop the environments within Dhurakij Pundit University. This campus still did not play a role as much it could and no policy to recruit disabled students. It was found that the proportion of buildings built before B.E. 2005 was higher than that of buildings built after B.E.2005. Universal design implementation may be more difficult, due to the cost of renovating older buildings is higher than investing in new buildings. Therefore, the legal requirements might be first important factor to push to be done in Dhurakij Pundit University. It is good, if the law explicitly stipulates for punishment those who do not comply. Since this case study had been in private university, which should support and avoid any mistakes to reduce defect, which would cost the damages. This will bring back the benefits to the business to be carried on. The main ideas to apply with the universal design in the campus was not only for the disabled, but if there is a motive for executives not to pay attention to the short-term conditions, universal design would support the quality of life, make the highlights to strengthen to be known and interested in all people as friendly university to all groups of people, good imagination. From the above might be the change of ideas to build the universal design for all people not only been done just for the legal requirements.

\section{Acknowledgements}

This research cannot be accomplished without the assistance and inspiration of Assoc. Prof. Dr. Antika Sawadsri towards research issue and methodology. Researchers would like to thank the executive managements of Dhurakij Pundit University and all interviewee for their cooperation in this study. 


\section{References}

Abdul Kadir, S., M. J. (2012). Building Managers' Perception in Regards to Accessibility and Universal Design Implementation in Public Buildings: Putrajaya case studies. Asia Pacific International Conference on Environment-Behaviour Studies (pp. 129-136). Famagusta, North Cyprus: Elsevier B.V. Selection.

Abdul Kadir, S., M. J. (2012). Applicability of Malaysian Standards and Universal Design in Public Buildings in Putrajaya. ASEAN Conference on EnvironmentBehaviour Studies (pp. 659-669). Indonesia: Elsevier B.V. Selection.

Afacan, Y., C. (2009). An interdisciplinary heuristic evaluation method for universal building design. Applied Ergonomics, 40, (pp.731-744) Department of empowerment of persons with disabilities, (2008). Ministerial Regulation: Education for Persons with Disabilities Act 2008, Section 5 [Online]. Available at http://dep.go.th/th/node/432.PDF (Accessed: January 2015).

Holley Atkinson, D. D. (2013, April 24). http://online.tarleton.edu/. Retrieved from http://online.tarleton.edul: http://online.tarleton.edu/ACEF/UDIL42413/.PDF. (Accessed: June 2015)

Jarutach, T. (2015) Universal design guide book [in Thai: คู่มือการออกแบบเพื่อทุกคน] In Jarutach, T. Operations Unit: Research environment for the elderly and disabled people, the Thailand Research Fund (TRF)

North Caroline State University, College of Design (1997). The Center for Universal Design, [Online]. Available at http://www.design.ncsu.edu/cud. (Accessed: June 2015)

Ostroff, (2001). The Centre for Excellence in Universal Design. Retrieved from http://universaldesign.ie: http://universaldesign.ie/What-is-Universal- Design/Benefitsand-drivers/.PDF (Accessed: August 2015).

Saito, Y. (2006). Awareness of universal design among facility managers in Japan and the United States. Automation in construction, 462-478. Elsevier B.V. Selection.

Sawadsri, A. (2012). 'Do I Look Like an Object?' A Quest of Exploring Person - Place Relationship of Disabling. ASEAN Conference on EnvironmentBehaviour Studies (pp. 418-428). Bangkok, Thailand: Elsevier B.V. Selection. 